Яременко Н. В., кандидат філологічних наук, доцент кафедри української та світової літератур Криворізький державний педагогічний університет

\title{
ОКСЮМОРОН ЯК ПРОВІДНИЙ ЗАСІБ ТВОРЕННЯ ХУДОЖНЬОГО СВІТУ ПОЕЗІЇ ФРАНСУА ВІЙОНА
}

Стаття містить аналіз функиіонування оксюморонних конструкиій в поетикальній системі лірики Франсуа Війона. Автором зроблено спробу вивчити антиномічну природу та специфіку творення оригінальних смислових якостей через використання оксюморона в поетичній традииї пізнього Середньовіччя. Виявлено, щуо художній світ Ф. Війона значною мірою базується на принципі іронічної гри, руйнування канонів $i$ приписів куртуазного письма, «семантичної зухвалості».

Ключові слова: оксюморон, Франсуа Війон, лірика, нонсенс, балада.

Статья содержит анализ функционирования оксюморонных конструкиий в поетикальной системе лирики Франсуа Вийона. Автором сделана попытка изучить антиномическую природу и специфику создания оригинальных смысловых качеств через использование оксюморона в поэтической традиции позднего Средневековья. Выявлено, что художественный мир Ф. Вийона в значительной мере базируется на принципе иронической игры, разрушении канонов и предписаний куртуазной письма, «семантической дерзости».

Ключевые слова: оксюморон, Франсуа Вийон, лирика, нонсенс, баллада.

The article contains the analysis of the functioning oxymoronic designs in poetically system lyrics of Francois Viion. The author attempts to study antinomic nature and specifics of the creation of the original semantic qualities through the use of an oxymoron in the poetic tradition of the late middle Ages. It is revealed that the art world F. Viion, in large measure, is based on the principle of ironic game, the destruction rules and regulations courtly letters, "semantic impertinence».

Key words: oxymoron, Francois Viion, poetry, nonsense, ballad.

У сучасному літературознавстві оксюморон розглядається як один із специфічних проявів художнього буття, що базується на концентрованій словесній опозиції, яка, у свою чергу, руйнує ціннісно-унормовані, логічно детерміновані системи [Бирдсли 1990:219]. Поетика оксюморона розглядається не лише як мовне утворення, для якого характерним $\epsilon$ поєднання непоєднуваного, а й як специфічне явище художньої реальності. У працях Л. Краснова, Л. Тимофєєва, Н. Кожевнікової, Н. Павлович, А. Ткаченка та ін. спостерігається інтерес до вивчення сутності поетичної природи й особливостей художнього функціонування цього феномена. У поле зору дослідників останніх десятиліть потрапила проблема вивчення оксюморона як метамовної одиниці, соціокультурного утворення, чутливого до ментальних 
особливостей митця. Численні потрактування терміну свідчать про його неоднозначність і складність.

Так, в «Літературознавчому словнику-довіднику» за редакцією Р. Т. Гром'яка трактування оксюморона зорієнтоване на його антиномічній природі: «оксюморон - цее різновид тропа, щ̧о полягає у сполученні різко контрастних, протилежних за значенням слів, внаслідок чого утворюється нова смислова якість, несподіваний експресивний ефект» [ЛСД 1997:505].

Як слушно зауважено І. Орловою, оксюморон, подібно до інших нелогічних утворень, порушує автоматизм сприйняття, звертаючи увагу читача на несподівані характеристики описуваного об’єкта, одночасно виступаючи засобом його пізнання. Поряд 3 іншими образно-аналітичними конструкціями, в основі утворення оксюморона лежить не формальна логіка, а інший спосіб сприйняття, де активну роль відіграє уява й асоціативне мислення [Орлова 2013:97].

На думку Е. Шестакової, оксиморон являє собою засіб творення алогізму в художньому контексті, що базується на нівеляції протиріччя, абстрагуванні від нього й концентрації на творенні оксюморонного образу як естетично цілісного явища, що зберігає пам'ять про антиномію як основу й межу. Як будь-який троп, оксюморон наділений складною структурою, до складу якої входить елемент продукування виразного смислу, який виникає на основі одночасного прояву контрасту i тотожності між елементами образної конструкції [Шестакова 2009:194].

Мета статті полягає в аналізі художньої функції оксюморона у творах Франсуа Війона та значенні цього прийому для формування специфічного авторського стилю поета пізнього Середньовіччя.

Поезія Франсуа Війона стала творчим підсумком розвитку середньовічної французької літератури й одночасно передвісником Ренесансу. Інформація про його життя має напівлегендарний характер і обмежується переважно судовими вироками та автобіографічними поезіями. 
Поет народився в Парижі 1431 року. Його справжнє ім'я - Франсуа 3 Монкорбьє. Восьмилітнім хлопчиком він утратив батька, і був усиновлений священиком Гійомом Війоном, настоятелем церкви святого Бенедикта, який став для нього «більше ніж батьком» («Великий заповіт»). У 1443 році Війон вступив на «факультет мистецтв» - підготовчий факультет Паризького університету - i влітку 1452 року отримав ступінь ліценціата й магістра мистецтв. Однак учені заняття його не дуже приваблювали. Він виявив себе не старанним учнем, що корпів над книгами, а справжнім шибеником неодмінним учасником гулянок, сварок, бійок, зіткнень із владою. Протягом усього життя невгамовний поет потрапляв у халепи (був звинувачений у ненавмисному вбивстві, крадіжках, бродяжництві тощо).

Творчість Франсуа Війона тісно пов'язана з лірикою трубадурів та поезією вагантів. Традиції попередників стали підгрунтям для новаторських пошуків митця. Вірші Ф. Війона характеризуються посиленням особистісного начала. Вони $є$ засобом індивідуально-неповторного самовираження особистості, на відміну від куртуазної поезії, де панував чіткий канон. Як зауважує А. Скрипник, у цілому «в цуей період однією з особливостей текстової організації стає посилення автобіографічності та особистісної орієнтації ліричного самовираження. Саме в рамках інтенсифікаџії особистісного начала, яке бере свій початок щее у творах поета XIII століття Рютбефа, слід говорити про найяскравішого представника поетичної творчості пізнього Середньовіччя Франсуа Війона» [Скрипник 2005:9].

Творчий доробок поета цілком вписується в поетикальну традицію Середньовіччя. Це стосується не лише віршованої та словесної техніки (метрика, строфіка, система рим, акровірші, анаграми і т. п.), а й специфіки жанру, тематики («колесо Фортуни», що то підносить, то скидає людей вниз, недовговічність жіночої вроди, смерть, що зрівнює всіх і т. п.).

Тематичний діапазон творів митця досить широкий. У поезї виразно звучить громадянська позиція автора, що вдавався до висміювання соціальних вад: збагачення шляхом пограбувань бідняків; паразитичного життя 
суспільної верхівки; політики самоуправства, егоїзму та зухвальства; хабарництва духівництва, далекою від благочестя й аскетичної стриманості життя служителів культу. При зображенні подібних явищ, що є втіленням авторського антиідеалу, поет застосовував засоби іронії та сатири. У ряді поезій він вдавався до викриття певних реалій шляхом оксюморонного висвітлення:

Праиює ледар безупинно,

Тиран нас милосердя вчить,

Найліпша в світі їжа - сіно,

Пильнує добре той, хто спить,

Хоробрий, хто в бою тремтить,

Найвища доброчинність - зрада, -

Лиш від закоханого ждіть

Найрозумнішої поради [ЛЗС 2003: 395].

Оксюморони «ледар працює безупинно», «тиран нас милосердя вчить», «пильнує той, хто спить», «найвища доброчинність - зрада» тощо репрезентують витончене переплетіння смислів, які унеможливлюють наявність логічної передбачуваності. При цьому певною мірою руйнуються ціннісні акценти, створюється специфічна настроєвість.

Неодноразово митець звертався до зображення тілесного боку кохання, розвінчання псевдоідеалів куртуазії. Цілий ряд його творів визначається відвертістю в передачі інтимних сторін життя, еротизмом, піднесенням різних сторін суто тваринного задоволення від гарної їжі, вина, зручного ліжка тощо. Куртуазна лексика i куртуазний образ закоханого виглядають пародійно. Відверто комічне забарвлення мають цілі епізоди «Великого Заповіту», такі, як: «Подвійна балада про любов», «Балада подружці Війона», «Епітафія» та ін.

Разом із тим поет неодноразово відтворював душевний стан людини, що відчуває себе під владою долі, усвідомлює іiі всемогутність та всевладдя, постійний пресинг. Ці твори характеризуються увагою до стану душі й духу ліричного «я» в даний, конкретний момент висловлювання, його субстанційного буття. Суб’єктом поезій є людина нужденна, сповнена 
драматичних переживань, але разом із тим не позбавлена волі визнати реальний стан речей, осмислити перипетії долі. Так, у «Баладі поетичного змагання в Блуа» внутрішній емоційний стан ліричного «я», його відчуженість від мешканців краю передано за допомогою прямих і переносних виражальнозображальних засобів. Застосована форма прямого називання на початку поезії створює емоційне поле трагічної самотності:

Чужинцеем в рідному краю блукаю,

Німую криком, мовчки я кричу, <..>

В стражданні є для мене щзастя хміль, Жебрак - скарбами світу володію,

Скрізь прийнятий, я гнаний звідусіль.

Непевний того, в чому певність маю,

Я бачу світло, як задму свічу,

I знаю тільки те, чого не знаю,

Знання химерним випадком вважаю,

Зірвавщи банк, весь програш я плачу [ЛЗС 2003:396].

Протиставлення в антиномічній парі «німую криком, мовчки я кричу» має парадоксальну природу (використання лексичних одиниць, значення яких взаємно заперечується) та передає неоднозначність психологічних реакцій ліричного героя або крайній прояв експресії: крик, який не передбачає зовнішньої реакції. Образ світла традиційно у сприйнятті пов’язується із метафізичним станом «всезнання», тому авторське твердження «бачу світло, як задму свічу» постає у свідомості читача як утвердження спроможності пізнання більшого, ніж раціональне, підпорядковане реальності.

Вічна боротьба інстинкту життя та страху смерті - ще одна грань осмислення світу в ліриці митця. Вірші поета стали ареною двобою болю й радості, щастя й страждання. У світі ліричного переживання опозиція земного й небесного набуває драматичної напруги. «Страждання розуміється поетом, як щзось закономірне, необхідне та всесильне, будь-який спротив йому буде марним. Проте водночас поет свідомо вказує на поняття, яке сильніше та могутніше за страждання - иее смерть» [Скрипник 2005:14]. 
Динаміка небесно-земних переживань ліричного героя виявляє зростання суб’єктивізації сприйняття смерті, що набуває різноманітних ознак. «Епітафія в формі балади, писана собі й своїм товаришам у чеканні шибениці» створена в часи ув'язнення, а саме в період очікування страти. Цим пояснюється образність твору: повішені апелюють до перехожих, закликаючи тих молити Бога про милість. У епітафії прихід смерті потрактовано як невідворотність, спущену з неба через гріхи. У ній підкреслено пасивність будь-якої людини перед смертю:

Ось висимо - n'ять чи шість нас, - i погас

Вогонь життя в тілах, таких бридких, -

Гниє і опадає м'ясо з них,

На порох перетліють скоро й кості.

Не кпіть із наших напастей лихих, -

За нас благайте Бога в високості.

Хай обирали ми шляхи криві,

Закон понищив нас, ніхто не спас, -

Та мудрощі не всім же в голові.

Не гнівайтесь, коли звемо ми вас

Братами, - тут уже не до образ [ЛЗС 2003:393].

Одночасно в цьому творі звучить заперечення смерті та відчувається жах людини перед загибеллю, страждання через руйнування тіла:

Нас мили й прали зливи грозові,

Пекло й палило сонще, вітер тряс,

Ставали ми поживою черві,

Сорокам, крукам чорним, $і$ не раз

На нас ненатлий птах свій голод пас,

I очі повиймав, $i$ з брів густих

Волосся вискуб, як солому з стріх.

Погляньте лиш, і вас охоплять млості.

Щоб не зазнать вам всім таких утіх,

За нас благайте Бога в високості [ЛЗС 2003: 393-394]. 
«Саме страждання від уявлення про спотворення тіла («souffrir la mort») має за стрижень поняття екзистенції, тобто самої суті свого «Я», звільненого від щоденних земних клопотів та понять. Адже мовець відкидає всі зовнішні чинники життя, він не думає навіть про духовні справи, не згадує важливі події свого життя. Він зосереджується на найінтимнішому, що можна висловити, як: «Я помру! Мене не буде! Навіть моє тіло вже буде не Я!». Якщо у творах Рютбефа смерть «кусає», «ламає ноги», то у Війона вона «спалює» людину: «mort me consume» - тобто знищує повністю, безповоротно і безнадійно. У його поезії вперше виявляється ставлення людини до власної смерті - вона ї̈ постійно оплакує через те, що смерть $є$ запереченням земного життя, сповненого земних задоволень: «Regrete huy sa mort et hier» <...> Caмe y nоезіi Війона суб’єктивізація сприйняття смерті досягає найвищої точки в порівнянні із творами інших поетів XII - XVcm.» [Скрипник 2005:17]. Образ смерті в його ліриці існує як певний елемент людської екзистенції, привід для людського терпіння та страху, а також як велика таємниця.

Ряд поезій митця порушують проблеми недовговічності, безцільності людського буття, вічного плину живої природи, суперечливості земного існування особистості та смерті. Поетичні рядки творів цієї тематичної групи сповнені драматизму від усвідомлення тлінності всього земного, згасання та перетворення живого в мертве. Наприклад, у «Баладі про дам минулих часів» автор, звертаючись до уявного читача, ставить риторичні питання: «Скажіть, в яких світах вона?», "Де вся та врода несказанна?», "Де всі вони, де їхня шана?»[ЛЗС 2003:392] і перелічує цілий ряд імен красунь (римлянка Флора, Архіпіада чарівна, королева Бланш, вельможна панна Аренбур, горда орлеанка Жанна та ін.). У творі акцентовано на колишній чарівності, незрівнянній вроді, славі жінок; на стражданнях чоловіків, ладних піти на будь-який крок з метою завоювати їхню прихильність. Ідея абсурдності життя, його швидкоплинності увиразнюється в повторенні приспіву «А де ж тепер торішній сніг?» [ЛЗС 2003:392]. Останні рядки твору відбивають усвідомлення 
ліричним «я» невідворотності смерті, руйнування краси, переходу з одного стану в інший:

Ні, принце, марна річ від рана

Й до вечора питать про них,

Бо приспівка незмінна й знана:

A де ж mепер торішній сніг? [ЛЗС 2003:392].

Оксюморонне поєднання суперечливих станів і відчуттів не призводить до фрагментарності художнього світу, a, навпаки, створює гармонійний мікрокосм, здатний саморозвиватись і вдосконалюватись. Пристрасна любов до життя в усіх його проявах, жага насолод визначають емоційно-експресивний тон більшості поезій автора.

Його іронізування спрямовано не лише на недосконалість зовнішнього світу, а й на ситуації особистого життя. Так, у «Великому Заповіті», ліричний герой постає хворим і вмираючим від любові без взаємності. Він розподіляє перед смертю своє, здебільшого неіснуюче, майно. Усі «спадки» мають жартівливий, глузливий, знущальний або непристойний характер - залежно від ставлення Ф. Війона до того або іншого «спадкоємця». Автор часто вдавався до антифразиса (вживання слів в протилежному значенні). Він вживав позитивно забарвлену лексику, для характеристики негативних тенденцій. Наприклад, у «Великому Заповіті» словами «спадкоємці», «найчесніший малий» позначав запеклих пройдисвітів; оспівував виразність зовнішності, говорив про людину як про «красеня» 3 метою виставити потворою; присягався в любові, маючи на увазі ненависть і т. п. Такі бурлескні «Заповіти» були канонічним жанром середньовічної поезії.

У багатьох поезіях митця відкрито чи приховано наявний адресат. Діапазон таких звертань широкий (мій принц («Балада поетичного змагання в Блуа», «Балада на прислів’ях», «Балада про дам минулих часів»), перехожі («Епітафія в формі балади, писана собі й своїм товаришам у чеканні шибениці», уявний читач «Балада неймовірностей» та ін.). Тут лірична ситуація моделюється самим процесом звертання суб’єкта лірики до адресата. 
Деякі 3 поезій, що будуються на прийомах інвокативної лірики, містять звертання на «ти», «ви». Таким чином, у поезіях помітні різноманітні форми об’єктно-суб'єктних відносин між автором (ліричним «я») - носієм ідейноестетичної концепції світу й об'єктом зображення.

Художній світ Ф. Війона заснований на іронічному й безжальному руйнуванні та знеціненні канонів традиційної поезії. Принцип поезії митця іронічна гра 3 усім традиційним, закостенілим, загальноприйнятим. Оригінальність творчості митця полягає передусім у творенні системи оксюморонних образів вибудуваних значною мірою за принципом т. 3. «семантичної зухвалості», через подолання стереотипності та творення нового естетичного цілого.

\section{БІБЛІОГРАФІЯ}

Бирдсли М. Метафорическое сплетение / М. Бирнсли. // Теория метафоры: Сборник: Пер. с анг., фр., нем., исп., польск. яз. / Вступ. ст. и сост. Н. Д. Арутюновой; Общ. ред. Н. Д. Арутюновой и М. А. Журинской. - М. : Прогресс, 1990. - С. 201-219.

Література західноєвропейського середньовіччя / за ред. Н. О. Висоцької. Вінниця : Нова книга, 2003. - 464 с.

ЛСД 1997 - Літературознавчий словник-довідник / Р. Т. Гром'як, Ю. І. Ковалів та ін. - К. : ВЦ «Академія», 1997. - 752 с.

Орлова 2013 - Орлова І. С. Відтворення оксюморона у перекладах творів Х. Л. Борхеса / I. С. Орлова // Науковий вісник Чернівецького університету. Випуск 645. Романо-слов'янський дискурс. - Чернівці, 2013.

Скрипник 2005 - Скрипник А. В. Французький поетичний дискурс епохи Середньовіччя : автореф. дис. на здобуття наук. ступеня канд. філол. наук : спец. 10.02.05 «Романські мови» / А. В. Скрипник. - К., 2005. - 20 с.

Шестакова 2009 - Шестакова Е. Г. Оксюморон как категория поэтики (на материале русской поэзии XIX - первой трети XX веков) / Элеонора Георгиевна Шестакова. - Донецк : НОРД-ПРЕСС, 2009. - 209 с. 